\title{
RESEARCH PAPER \\ Human resource management in small and medium-sized vineyards in Chile
}

\author{
Gregorio Pérez Arrau ${ }^{1}$ and Felipe Muñoz Medina ${ }^{2}$ \\ ${ }^{1}$ Facultad de Administración y Economía, Universidad de Santiago de Chile. Avenida Libertador Bernardo \\ O’Higgins 3363, Estación Central, Santiago, Chile. \\ ${ }^{2}$ Facultad Tecnológica, Universidad de Santiago de Chile. Avenida Ecuador No 3769, Estación Central, \\ Santiago, Chile.
}

\begin{abstract}
G. Pérez Arrau, and F. Muñoz Medina. 2014. Human resource management in small and medium-sized vineyards in Chile. Cien. Inv. Agr. 41(2): 141-151. The focus of this paper is the identification of human resource management practices in small and medium-sized vineyards in Chile, identifying agents and relevant groups that allow a better understanding of how these companies manage their human resources. The research is based on 22 interviews held with personnel managers and key informants from a total of 16 wine-producing vineyards between 2009 and 2012. The research involved collecting studies and analyzing the specialized literature on human resource management in small and medium-sized enterprises (SMEs). The research highlights the features, relevant problems and challenges of human resources management with the aim of improving production, innovation and long-term sustainability. Although the wine industry is an emblematic economic area of Chile, how it manages its human resources is unknown, so this research focuses on this little-known area that is so important to productivity.
\end{abstract}

Key words: Human resource management, wine industry, SMEs, Chile.

\section{Introduction}

This research was carried out in an emblematic economic field in Chilean society, the wine industry. This industry can be considered one of the most successful business domains in Chile, and it ranks among major world producers. It should be noted that the total exports between January and July 2012 reached US $\$ 786.3$ million, which is $2.7 \%$ more than the year 2011; US\$ 416.6 million of that total belongs to ten of the country's winer-

Received June 27, 2013. Accepted April 8, 2014. Corresponding author: gregorio.perezarrau@usach.cl ies, representing $53 \%$ of the national revenue. The exported volume amounted to 30 million liters. In 2013, the total exports reached US\$1,879 million, with 879 million liters at an average price of US\$ 2.1 per liter. Regarding bottled wine exports, in the same year, the more than $20 \%$ growth rate in the demand from the Japanese and Chinese markets is particularly notable. Bulk wine exports increased $50 \%$ with respect to 2012 , mainly due to the demand from countries such as China, Spain, the United Kingdom, and Germany (Vinos de Chile, 2014).

The success of the Chilean wine industry is fascinating, not only because of its financial 
earnings but also because it is not merely a commodity. Wine production involves not only the use of raw materials like grapes but also the industrial process of wine making and its connection with related production processes such as the manufacture of bottles, corks, and labels. Furthermore, wine production requires the expert knowledge of enologists, grape growers, and marketing specialists, who apply their experience to every aspect of the production process.

These aspects of wine have led many people to state that it is a symbol of Chile's economic success and that it is changing the country's identity. In this sense, this research hopes to contribute to the knowledge of how work relationships are shaped in this very important and specific sector and contribute to the improvement of the workers' conditions and productivity.

Human resource management in Small and Medium-Sized Enterprises (SMEs)

SMES: the great unknown. Throughout the brief history of what has been called the human resource management (HRM) paradigm, SMEs have hardly been considered a matter of interest; instead, it has been assumed that the same principles that apply to large companies can be applied to smaller ones (Mayson and Barrett, 2006; Bacon and Hoque, 2005; Casssell et al., 2002). In this sense, Tansky and Heneman (2003) have noted that in the literature on human resource management, SMEs are treated as "second class citizens". Moreover, investigators do not yet agree on what are the most significant factors that determine direct human resource management, and little academic research has been devoted in this area of knowledge. Tansky and Heneman (2003) describe the present state of human resource development in SMEs as "under observation," waiting for the development of taxonomies and frames of reference on this subject.

\section{The importance of HRM in SMEs}

Various studies suggest that SMEs are gaining more importance in the present economic dynamics (Fuschetti and Pollack, 2011). According to the European Commission's Annual Report on SMEs in the EU, 2011/12, micro, small, and medium-sized companies constitute approximately $98 \%$ of all formally established companies, and in countries such as Spain, this figure is above $99 \%$. In turn, in the European Union, small and medium-sized companies generate almost two-thirds of jobs.

The Chilean SME context is not different. According to the Chilean government and the Ministry of Economy, approximately $80.8 \%$ of formally established companies are microcompanies, $18.2 \%$ are SMEs, and only $1 \%$ are large companies. Accordingly, SMEs generate almost $70 \%$ of the country's employment, and $90 \%$ of the wage-earning jobs created during 2011 were generated by very small companies and SMEs, i.e., companies with a maximum of 200 employees. Nevertheless, as in most other countries, Chilean SMEs face problems such as weak demand, financing difficulties (loans), delays in payment, and unequal (unfair) competition, giving rise to complex and difficult conditions for their management.

Evidence shows that HRM is generally given low priority in SMEs; however, it is considered by their owners to be one of the most important and complex problems to be solved (Wilkinson, 1999). In these companies, HRM can be especially important because they are generally labor-intensive companies and because each employee represents a significant part of the work force and intellectual capital. For this reason, attracting, developing, and retaining competent and talented workers becomes a fundamental survival task that can have many benefits (Brand and Bax, 2002;). At the same time, the advantages of HRM in SMEs are the improvement of adaptation capacity and performance, attraction and retention, commitment, organizational effectiveness, and in general, 
long-term growth and sustainability of qualified workers (Cardon and Steven, 2004; Brand and Bax, 2002; Mayson and Barrett, 2006;). On the other hand, the negative consequences of less sophisticated HRM include unfair layoffs, less work stability, lack of qualified work, insufficient recruitment practices, scarce training, absence of performance assessment, and minimal application of equal opportunity policies (Bacon and Hoque, 2005).

\section{What do we know about HRM and SMEs?}

The subjects mentioned most frequently in the current literature are acquiring, compensating, and motivating workers, while training, performance management, retaining labor force, labor relations, and organizational change have received less attention (Cardon and Steven, 2004). Thus, it is known that SMEs seldom have formal HRM practices and policies, and when they do, they tend to be disorganized or incoherent, also known as a pick and mix approach, creating policies or adopting techniques according to contingency or even by chance, without necessarily having a clear and strategic plan. Furthermore, studies show that the approach to HRM is determined by factors such as the existence of an "HR defender" in the company, current rules and regulations, the results of past experience in implementing HR policies and practices, and finally, awareness of current HR trends (Cassell et al., 2002). Similarly, other recent studies have been aimed at subjects such as innovation and how the formality of HR is involved in innovation (De Saá et al., 2012;).

Weak management leads administrator-owners to have a dominant role in the overall administration of the business, including strong involvement in personnel matters (Beaver and Hutching, 2004; Cardon and Steven, 2004; Bacon and Hoque, 2005; Mayson and Barrett, 2006). Additionally, some studies have shown that in firms with up to 50 workers, it is the owners who perform most personnel functions. With this in mind, it is pos- sible to state that the owner's personality plays a fundamental and decisive role in the application of more sophisticated human resource practices (Brand and Bax, 2002; Bacon and Hoque, 2005; Mayson and Barrett, 2006).

Small companies rarely have creative and sophisticated human resource plans, creative and sophisticated recruiting methods, or selection and motivation techniques. Due to market pressure, small companies tend to make only short-term-oriented decisions. Additionally, these companies have less people management knowledge and experience than large companies, and employing personnel specialists is not considered necessary (Wilkinson, 1999).

In the available literature, various human resource management functions that are different from those of large companies have been described. For example, in SMEs, the recruitment process is problematic due to the lack of resources for hiring specialists, which is attributable to the absence of more sophisticated selection techniques (Mayson and Barrett, 2006). Generally, in this type of company, recruitment is focused on internal candidates and is characterized by sporadic and contingent (ad-hoc) procedures. In this scenario, it is not difficult to fill a vacant position with internal candidates because "common knowledge" of the business is shared by all group members, and therefore, there will always be someone ready to assume the responsibility. Thus, when there are no appropriate internal candidates, the recruitment process usually considers informal contacts, personal references from employees, and newspaper advertisements (Cardon and Steven, 2004; Mayson and Barrett, 2006; Beaver and Hutching, 2004; Cassell et al., 2002). This process may even include the use of administrator-owner contacts such as relatives, friends, neighbors, and present or past employees, which create a problematic intertwining of family or friendship bonds with business rationality.

Regarding employee development, it has been noted that training in SMEs is limited by costs as 
well as by lack of strategic objectives, long-term vision, and adequate diagnosis of needs (Beaver and Hutching, 2004; Brand and Bax, 2002). It has also been stated that the training that is provided is not of the required quality and that it does not improve company performance. In general, the evaluation of training needs in SMEs tends to be based on personal estimation, expectations, intuition, and a short-term outlook by the administrator-owners, instead of on a more strategic approach (Matlay, 1999). The same applies to training methods in the workplace, which are generally applied through practice and instruction at the work position, which is a cheaper way of carrying out training (Brand and Max, 2002; Delahaye, 2003). In this way, training is rarely assessed, and when it is, the criterion used is still a subjective appraisal by the owner (Beaver and Hutching, 2004). Additionally, the lack of funds results in a low level of training, which creates one of the main causes of high worker turnover in SMEs, i.e., the poor career opportunities offered by the employers (Storey, 1999). Furthermore, a paradoxical situation develops: among the small number of SMEs that can finally implement some type of training, the training indirectly results in the loss of employees because they become more attractive in the labor market for large companies (Cassell et al., 2002).

Regarding performance evaluation, studies show that the use of formal systems can reduce absenteeism and turnover and improve employee performance and satisfaction (Beaver and Hutching, 2004), although this type of practice is extremely unusual among SMEs (Cassell et al. 2002). Furthermore, it should be noted that one of the main barriers for implementing formal evaluation systems is precisely the administratorowner, who might prefer the traditional, personal, $a d-h o c$ and arbitrary system that is not systematic or standardized, instead of a formal evaluation system (Beaver and Hutching, 2004; Cardon and Steven, 2004; Cassell et al., 2002). Lastly, the perception by the employees that they are being treated unfairly as a result of the administratorowner's personal approach can lead to feelings of anger and frustration, followed by lack of commitment, and finally to resignation from the company (Wilkinson, 1999; Beaver and Hutchings, 2004). Consequently, there are relevant correlations between human resource formality, employee satisfaction, and work commitment (Saridakis et al., 2013).

There is absolute consensus among specialists that SMEs cannot compete with large companies with respect to compensation. In this sense, the latter attract the "best talents" in the labor market because they have more resources, and therefore, SMEs are more vulnerable to losing employees (Cardon and Steven, 2004). Additionally, SMEs rarely have a systematic approach to salaries or a formal payment structure; salaries are defined by idiosyncratic criteria and negotiations (Beaver and Hutching, 2004; Cardon and Steven, 2004), with considerably inferior benefits (Cardon and Steven, 2004; Brand and Bax, 2002). Nevertheless, in terms of intrinsic rewards, SMEs have greater maneuvering power to offer attractive employment conditions in terms of autonomy, responsibility, recognition, flexibility, and a wider range of participation in decision-making in the case of talented workers (Beaver and Hutching, 2004).

Finally, there is relative consensus that the familial nature of the SMEs is an obstacle to their functioning and development. Among the commonly mentioned problems are the management of assets, an inefficient company structure, a low level of institutionalization and professionalization of the management, generational replacement conflicts, and deficiencies in communication decision making, among others (Kontinen and Ojala, 2012).

\section{Materials and methods}

\section{Research question}

Considering the background described above, the importance of the wine-making industry in Chile, and the emerging knowledge on HRM in 
this emblematic business, this research was carried out based on the following questions: What types of human resource practices are there in Chilean vineyards? To what extent are they formalized? What are the main challenges that this area faces regarding HRM?

\section{Sample size and type of study}

The sample consisted of 16 small and mediumsized vineyards, from which information was gathered in 16 interviews with managers and/or personnel managers and six (6) interviews with key wine-making experts.

These interviews provided relevant information to delve into the state, processes, and challenges of HRM in small Chilean vineyards, as well as to understand their needs and future perspectives.

Considering that, according to the Chilean National Statistics Institute (Instituto Nacional de Estadísticas de Chile, 2004), there were 451 vineyards in the central area of the country (between the Coquimbo and Bío Bío Regions) that directly employed approximately 1,700 people, including professionals, technicians, administrative personnel, workers, sales personnel, and other workers in diverse areas, it is evident that the sample used cannot be considered completely representative. Consequently, this study is presented as an exploratory analysis through which we hope to establish an initial understanding of the reality of HRM in Chilean vineyards, with the purpose of identifying relevant categories and facts that will allow further research into the subject in the future.

\section{Procedure}

As a first approach, interviews were carried out with managers and/or personnel administrators from the SMEs vineyards that were contacted, who agreed to participate voluntarily. These interviews were conducted in the same geographical location as the workplaces. Later, five (5) interviewees were contacted by email or phone to briefly gather more in-depth information on some observations.

\section{Instrument}

Each interview was recorded on a long-lasting digital recorder and took approximately 40 minutes. The interviews were semi-structured and referred to 1) human resource policies and practices, 2) the perceived results of human resource management practices, 3) the role of human resource units, 4) significant changes in and influence of the environment, and 5) the main problems and challenges of the vineyards.

The epistemological approach on which the research was based and the interviews were guided is the pragmatic approach, understood in the sense used by James (2002) as the search for a discourse that allows understanding not only of the processes but also of the actions that the subjects perceive. The data interpretation was carried out manually by content analysis and the development of categories.

\section{Results and discussion}

The reality of SMEs in the Chilean winemaking industry

Relevant groups. To understand personnel management in Chilean PYMES vineyards, it is essential to distinguish among three different groups of employees who make up their work force: 1) highly qualified workers (professionals and specialized technicians) and knowledge workers, 2) typical permanent workers (chiefs, technicians, and workers), and 3) seasonal workers. These three employee groups have different types of relationships with the companies, work under different plans, and are subject to different human resources and practices. To understand 
these diverse groups, it is useful to refer to the model of human resource architecture developed by Snell et al. (1999), which is an interesting analogy that helps to illustrate that the composition of a company's work force is diverse and consists of employee groups of different natures and functions, who should be treated in particular ways depending on their needs, strategic value for the company, and uniqueness, leading to diversity in human resource practices and the generation of different levels of commitment and responsibility among the employees.

The first significant group consists of highly qualified professionals with a high level of experience. In this group, we can also identify some specialists who clearly qualify as knowledge workers because they perform complex, unstructured, changing, and creative tasks and are responsible for product and process innovation. In this group, enologists stand out, and they are considered the rainmakers because they coordinate the team effort of other knowledge workers, directing the overall production process. This group also includes the winemakers, marketing specialists, suppliers, and the owner of the vineyard, who participate at the highest level of the company's organization chart and together contribute the necessary experience to achieve quality wine (Pérez Arrau, 2010).

The second important group includes permanent workers, some of whom have a basic education level and are in charge of low responsibility tasks. This group operates as an intermediary between CEOs and less qualified workers and are referred to as central employees or coreworkers, who can be considered to be the employees who the firm considers permanently necessary and critical to the organization's activities.

The third significant group corresponds to seasonal workers or temporeros, who have participated in winemaking since the beginning of agricultural production in the first vineyards reported during the colonial period in Latin America and Chile (Lacoste, 2007). They were generally men and/or women from the surrounding land areas, and they provided services such as shoot removal, grape picking, planting, and pruning, among other activities. Nevertheless, there is also a phenomenon that can be called floating immigration, referring to workers who arrive from other territories in search of work for as long as it lasts.

It is estimated that, in Chile, close to 750,000 people work in the agriculture sector, and of those, 450,000 work in the fruit area, 180,000 are permanent workers, and 250,000 are temporary workers. The latter type of worker is required for limited periods of time when greater productivity is required, sometimes doubling or tripling the company's stable population.

\section{Human resource practice in important groups}

Highly qualified workers: professionals, specialized technicians, and knowledge workers. This particular group requires the most sophisticated human resource practices, basically because its human resources are also sophisticated, and consequently, the financial resources used by the companies for this group are also greater. HRM aspects such as recruiting and selection are more specialized, and therefore, the relevant practices may include advertising, contacting specialized consultants and related companies at the management level, and carrying out psychological testing, especially for management and highly specialized technical jobs. Interviews are still the main instrument to get to know the candidate. However, the fundamental role played by informal contacts in these processes cannot be ignored because many of the specialists working for these vineyards were hired by word of mouth, confirming the findings of Pérez Arrau (2010).

The induction training programs provided to this group are few and are related to safety, areas to be used by employees, procedure manuals, and training. However, enologists share their knowledge at congresses and meetings to acquire new 
technical abilities, especially through formal and informal presentations. By contrast, group performance evaluations are carried out in annual or semi-annual meetings to verify compliance, not through formal instruments but rather through the management's perception and data on compliance. Compensation for this group is more specialized, delivering more well-being, and stronger retention policies are applied. Examples of this more specialized compensation include bonuses of a variable nature depending on goal achievement, although they often have no relation to the responsibilities of each worker but rather with the area in which the job is performed. Particularly, most of those interviewed stated that production and sales employees are paid more bonuses because these areas tend to be more important in terms of the generation of income for the vineyards. Similarly, the payment structure is related to inorganic growth, which is central in the present debate in the sense that there is strong pressure for companies to attract, retain, and motivate knowledge workers, within the framework of a dynamic labor market in which young professionals have multiple job options.

On the other hand, career development is related to the experience and knowledge that the group members can acquire for their own professional development. Because it is not possible to reach higher positions within the organization due to its reduced size, the professionals' careers evolve by changing jobs to different companies and industries.

Typical permanent workers: chiefs, technicians, and workmen. Recruitment is conducted mostly based on word of mouth among known members in the surrounding areas or in nearby vineyards. As a particular case, some vineyards contact schools that train agricultural technical professionals, with the purpose of recruiting students. Regarding selection, the criteria include experience parameters and knowledge of some basic functions, the most important of which is handling production, loading, and transporting equipment, as well as knowledge of the operation and maintenance of bottling lines; thus, finding a worker with this knowledge is valuable for the company.

Accordingly, the induction training is not a very sophisticated process; rather, it consists of a basic description of how the company works, and the tasks related to wine cellar activities, production, and equipment operation. On the other hand, training is restricted to the handling of pesticides, fertilizers, and safety, with the exception of training related to quality and health certification, which has impact on the demands of importing countries. This leads to the creation of procedure manuals; although not yet present in many vineyards, the intention to create such manuals are mentioned in terms of a willingness to prepare these employees, particularly to comply with international quality regulations and compulsory certifications. Moreover, in general, evaluations are carried out once a year. They are not formal instruments but rather conversations and/or meetings, verifying that the workers have complied with all the programmed activities involved in their functions (checklist).

Some compensation practices include price discounts for workers for the products produced by the vineyard (wine, cheese, "manjar", and others), family field trips financed by the company, and productivity bonuses. With regard to salary, compensation depends on rank within the vineyard's hierarchy and its corresponding responsibilities. The same applies to bonuses, although bonuses are somewhat different because they are related to and depend on production and sales achievements, so they are given to personnel who work in the cellar, sales, and marketing.

On the subjects of quality of life, safety and hygiene, many of the studied vineyards have started taking action in the form of exercise programs to introduce relaxation and health care practices to workers, as well as talks, training, and the introduction of safety and hygiene practices that are developing, especially in the areas of cellars, production, and pesticides. Additionally, accord- 
ing to the law, when a company has more than 25 employees, it is obliged to facilitate the creation of a "joint committee" in which workers and administrators approach labor safety problems and take preventive measures.

It should be noted that unions in particular have had an important influence in this matter, although they are small and are frequently forced to make use of collective agreements and/or negotiations between the finance and operations managers to solve their conflicts. However, it should be noted that when this issue was brought up with the interviewed vineyard managers, they did not see any problems with the formation of unions.

Seasonal workers. Planning the number of seasonal workers is directly related to planning the vineyards' grape production, and although this is very important, there is no structured mechanism for doing so, and it is carried out on a contingent basis. Recruitment methods are put into practice in diverse and informal ways, which in many cases turn out to be unusual. One of the most frequent methods is contact by word of mouth from seasonal workers, who tell other workers about vacancies. Other unusual practices include using megaphones in the town squares and centers of some geographic zones where the vineyards are located, offering jobs to passersby. Some local municipal employment agencies have collaborated in this recruitment by providing the community with information on jobs. The selection mechanism is based on the worker's experience and motivation, and there is no accredited specialization of any type in relation to the job to be taken. It must also be noted that a shortage of employees often requires ignoring the applicant's experience and motivation screenings, as there is no choice but to hire.

On the other hand, the vineyard's training and induction plans are vague and are provided by other state institutions such as the OTIC, which carries out training on workplace safety, risk prevention, and handling of pesticides. To this end, vineyards make use of the SENCE subsidy, which allows companies to significantly reduce their training costs.

Work evaluation mechanisms, as well as job descriptions and evaluations, are not formal, but daily and pertinent observations made by the field supervisor or team leader contribute to the appropriate development of such mechanisms. Furthermore, there is no evidence of the existence of a procedure manual or of the standardization of job functions, which results in a lack of information on the actions to be carried out, causing worker resignations because they are not aware of how complex and difficult the job is.

\section{Communication and coordination between} the vineyards and seasonal workers is usually implemented by posting signs on bulletin boards, sending e-mails, organizing group meetings, and sending out mailings. More rarely, a cell phone is used to make calls or send messages, which reduces the asymmetry of information available to workers, allowing them to be better informed about possible job vacancies and salaries offered by the vineyards and other companies that offer similar jobs, allowing them to suddenly change jobs, demonstrating that information and monetary incentives play an important role. There are differences in the way the vineyards pay workers: in some, wages are proportional to the amount of grapes picked and are increased according to goal achievement; in others, wages are based on an agreement between the employee and the employer, regardless of the job to be performed. Very few unions are created because seasonal workers are not a stable labor force.

\section{The invisible collaboration: the "enganchador".} In relation to the provision labor, this research identified a very important character known as the "enganchador," who has information on possible workers who work on a day-by-day basis in surrounding vineyards and perform other field tasks. Recent studies have defined the role of the "enganchador" as a paid function for recruiting 
and transporting workers for a specific task or job ultimately provided by another employer (Caro, 2012), "Enganchadores" are not contractors because they do not offer direct services to the vineyards and do keep in contact with them. They offer their services to contractors, who get in touch with them for contacts and workers when they cannot obtain them directly. The "enganchador" is usually a person who knows many people in the surrounding areas and is always in contact with them via cell phone or through acquaintances. It is estimated that $20 \%$ of the producers use the services of these intermediaries to obtain temporary workers (Anríquez et al., 2014). The role of "enganchadores", the way in which they operate, and their relationship with the contractors is one of the lesser known areas in the dynamics of farm work (Anríquez et al., 2014)

In summary, there are three main conclusions to be drawn from the present study. First, three groups relevant to human resource management have been identified: 1) highly qualified workers (professionals and specialized technicians) and knowledge workers; 2) typical permanent workers (supervisors, technicians, and laborers); and 3) seasonal workers. These groups are affected by diverse labor relations, policies and practices. The differences between these groups that constitute the human resources architecture suggest that vineyards should develop specific strategies, focusing on the needs of each group and searching for more attractive ways to attract, retain, motivate, and develop their personnel.

Second, the data collected in this study confirm previous observations regarding the lack of sophistication and professionalization of human resource policies and practices in the agriculture sector in general, and particularly among small winemakers. There is almost no formalization of human resource management policies and practices. Specialized human resources departments or related professionals are almost nonexistent, and HRM decisions are made on a "pick and mix" basis rather than with a strategic outlook.
It is troubling to find that aspects such as labor relations, retirement management, union development, human resource planning, and organizational development plans are carried out on such a traditional, ad hoc, and informal basis by the general management, which certainly has a negative impact on employees and final productivity. This lack of formalization affects the ability of companies to attract and retain seasonal workers, highly qualified workers, and knowledge workers, who are migrating to more attractive economic areas such as the mining industry.

Third, it is possible to recognize in many vineyards the phenomenon known as "forced evolution" or "forced growth" described by Goffy and Scase (1995), in which a small organization is made to formalize and improve its administration policies and practices because of environmental pressure. In this regard, and considering the strong orientation of the Chilean economy toward global markets, more stringent demands would be expected regarding management and product quality, impacting HRM. Additionally, the growing interest shown by the vineyards in management models that include ethical standards, such as Corporate Social Responsibility (CSR) (Duarte Alonso and Bressamn, 2013) and Fair Trade (Kleine, 2008), suggest that HRM policies and practices will gradually increase in formalism and sophistication, in accordance with international ethical standards. Consequently, organizations should seek to implement high-standard HRM policies and practices, such as reward and recognition systems to stimulate new ideas and create a culture of innovation, so that they can better adapt to the new demands of the external environment.

\section{Acknowledgements}

We would like to express our gratitude to the Departamento de Investigaciones Científicas y Tecnológicas (DICYT) and Vicerrectoría de Investigación, Desarrollo e Innovación, and Universidad de Santiago de Chile. 


\title{
Resumen
}

\begin{abstract}
G. PérezArrau y F. Muñoz Medina.2014. Administración de recursos humanos en pequeñas y medianas viñas en Chile. Cien. Inv. Agr. 42(2): 141-151. El objetivo de este artículo es la búsqueda de prácticas de gestión de recursos humanos en pequeñas y medianas viñas en Chile, identificando agentes y grupos relevantes que permitan una mejor comprensión de cómo estas empresas gestionan sus recursos humanos. La investigación se basa en 22 entrevistas realizadas a directores de personal e informantes claves de un total de 16 viñas productoras de vino entre los años 2009 y 2012. Se incluye la recolección y análisis de literatura especializada sobre gestión de recursos humanos en PYMES. La investigación muestra características evidentes, problemas y desafíos con el objetivo de mejorar la producción, la innovación y la sostenibilidad a largo plazo. A pesar de que la industria del vino es un área económica emblemática de Chile, la forma en que administra sus recursos humanos es desconocida, por lo que esta investigación se centra en esta área poco conocida tan importante para la productividad.
\end{abstract}

Palabras clave: Gestión de recursos humanos, industria vitivinícola, PYME, Chile.

\section{References}

Anríquez, G., W. Foster, O. Melo, J. Subercaseaux, and A. Valdés. 2014. Empleo Estacional en la Fruticultura en Chile. Informe Proyecto FIA. Departamento de Economía Agraria, PUC.

Bacon, N., and K. Hoque, 2005. hrm in the sme sector: valuable employees and coercitive networks. International Journal of Human Resources Management 16:1976-1999.

Beaver, G., and I. Hutchings. 2004. The big business of strategic human resources management in small business. In: Steward, J., and G. Beaver (ed.). HRD in Small Organisations. USA: Routledge.

Brand, M., and E. Bax. 2002. Strategic HRM for smes: implications for firms and policy. Education Training Journal 44:451-463.

Caro, P. 2012. Magnitud y características de la participación laboral en el empleo temporal agrícola en Chile. Si Somos Americanos. Revista de Estudios Transfronterizos 12:51-83.

Cardon, M., and C. E. Stevens. 2004. Managing human resources in small organization: what do we know?, Human Resources Management Review 14:295-323.

Cassell, C., S. Nadin, S. Gray, M. and C. Clegg. 2002. Exploring human resources management practices in small and medium sized enterprises. Personnel Review 31:671-692.

De Saá, P., L. Díaz, and J. Ballesteros. 2012. The role of training to innovate in SMES. Journal Innovation: Management, Policy \& Practice 14:218230.

Duarte, A., and A. Bressan. 2013. Small rural family wineries as contributors to social capital and socioeconomic development. Community Development 44:503-519.

European Commission. 2012. Annual report on small and medium-sized enterprises in the EU, 2011/12, Available online at: http://ec.europa.eu/ enterprise/policies/sme/facts-figures-analysis/ performance-review/index_en.htm (Website accessed: September 1st, 2013).

Fuschetti, K., and J. Pollack. 2011. Addressing personal and family transitions in small businesses: effective human resources management practices. In: Cooper, Cary L., and R.J. Burke (eds.). Human Resources Management in Small Business: Achieving peak performance. Edward Elgar: UK.

Goofee, R., and R. Scase. 1995. Corporate Realities: Dynamics of Large and Small Organisations. London: Routledge.

Instituto Nacional de Estadísticas de Chile, INE. 2004. Enfoque Estadístico: Bodegas de Vino 
en Chile: Desde Coquimbo a Biobío. Available online at: http://www.ine.cl (Website accessed: October 11, 2004).

James, W. 2002. The meaning of truth. New York; Dover Publications. Originally published in 1909.

Kleine, D. 2008. Negotiating partnerships, understanding power: doing action research on Chilean Fairtrade wine value chains. The Geographical Journal 174:109-123.

Kontinen, T., and A. Ojala. 2012. Internationalization pathways among family-owned SMEs. International Marketing Review 29:496-518.

Lacoste, P. 2007. Complejidad de la industria vitivinícola colonial: Crianza biológica de vino (Reino de Chile siglo XVIII). Latin American Research Review 42:154-168.

Mayson, S., and R. Barrett. 2006. The science and practice of HRM in small firms. Human Resources Management Review 16:447-455.

Pérez Arrau, G. 2010. Managing knowledge workers: the case of the Chilean oenologists. Doctoral dissertation. University of Liverpool Management School.

Saridakis, G., R. Muñoz., and S. Johnstone. 2013. Do human resource practices enhance organizational commitment in smes with low employee satis- faction?. British Journal of Management 4:445458.

Snell, S., A. Lepak., and M. A. Youndt. 1999. Managing the architecture of intellectual capital: implication for strategic human resources management. Research in Personnel and Human Resources Management. Supplement 4:175-193.

Tansky, J., and W.R. Heneman. 2003. introduction to the special issue on human resources management in SMES: a call for more research. Human Resources Management 42:229-302.

Matlay. H. 1999. Employee relation in small firms. Employee Relations 21:285-295.

Delahaye, D. 2003. Knowledge management at SMES. International Journal of Organizational Behaviour 9:604-614.

Storey, J. 1999. Human resource management policies and practices in SMEs in the UK: does it really influence their performance?. Centre for Small and Medium-Sized Enterprises. Warwick Business School.

Wines of Chile. 2014. Información y Estadística, año 2013. Available online at: http://www.vinosdechile.cl/contenidos/informacion/informacion (Website accessed: May 20, 2014).

Wilkinson. A. 1999. Employment relations in SMEs. Employee Relations 21:206-217. 
